\title{
A Seed Op-Ed
}

\author{
Steven N. Handel
}

[Note: Restoration scientists and practitioners are always talking about the plants and methods they are using to initiate populations. A recent posting to the Editorial Office was received wanting, we suppose, respect for a seed. It is reprinted here.]

To the Restorationist:

\section{WHAT ARE YOU DOING? DON'T YOU KNOW?}

I ' $m$ hauled and slung around like I was inert, some small pebble! I'm alive; I'm complex; I have needs; I want a future. Look at me, Buster! Do you know what I've gone through to be ready for planting?

Even getting fertilized and maturing were terrors. So if plant populations are restored with no thought to the availability of required pollinators and their breeding and feeding niches, you know how many flowers in the fields never get visited? It's a pollination desert out there. As if some green leaves and pretty posies will create a sustainable population without our beloved mutualists, and that's just the beginning! Growing up on the maternal plant is the next horror. A huge number of seed herbivores are the norm. Where's the availability of parasitoids or other trophic specialists that attack my enemies on restored lands? I'm on my own half the time, dependent on my bracts and toxins and rapid maturation to get out of here before being found. Oh, for a happy childhood; it's not to be for us seeds. Just when maturation is almost complete, in comes some restoration crew to cut down the stalks so the plant community looks neat during the dormant season. Can you wait 'til my development is complete? Can you wait 'til I disperse by the wind or some animal? Mowers are a nightmare for so many seeds in the pasture. We spend all this time evolving fleshy fruit, or parachutes and pappus for wind dispersal, or floating bracts to get us away from home. The number of restoration projects that pay no attention to dispersal agents is a crime, a crime against demography. How about some surrounding habitat to facilitate populations of animal dispersers or some connected waterways to allow floating seeds to flow and reach favorable sites? Without dispersal, a seed drops next to the mother plant

Ecological Restoration Vol. 29, No. 4, 2011

ISSN 1522-4740 E-ISSN 1543-4079

(O2011 by the Board of Regents of the University of Wisconsin System. and it's shade, shade, and more shade. "I'm outta here" is a cry for survival, not of rebellion, so let's have some help!

Finally we seeds hit the ground, but oh, so often, it's not a happy landing. Where are the safe sites we need to facilitate germination? The number of times seeds land in a smooth and compacted surface is outrageous. We want scarification, we want heterogeneity, we want microsites! Do you know this story of the dozer operator who was trained grading the ground smooth as a sign of professionalism? The restorationist had to give her a few beers so she spun the dozer around in circles roughing up the surface, giving high biodiversity of plants a chance. We need disturbances. We need cleared areas. Some of my friends from the southwest even need a fire before they can get going.

We seeds are a little odd; I won't deny that. We like to be buried alive. Broadcasting seed, like for some hydroseeded fescues, is a waste of your time and death for so many of us. It takes longer and it takes more money, but if you want survival, cover me up. Then I need some time, don't rush me. Dormancy requirements are deliciously complex and fly in the face of your desire for fast greening of the site. Seed dormancy comes in at more flavors than Baskin Robbins: chemical, induced, mechanical, skotodormancy, physiological, morphological. But the dormancy gets me past the rough times, so don't rush me, kid. Breaking dormancy is usually something you restorationists have no control over. Don't wave a magic wand to get me to germinate; try fluctuating temperatures, drying, fire, low temperature, microbial action, scarification, animal passage (then defecation or regurgitation). Not so easy, you say? It's not so easy for me, either. Coming up out of the ground is the chanciest part of my life history. The number of seeds on the ground will never equal the number of seedlings, no matter what your contract guarantees say. And how much time did you spend picking the right ecotype for the soil you're working on? Every agricultural scientist goes through a long list of varieties matching genotype with site conditions. When is this going to be normal procedure for the restoration crowd? Even when in the ground, the life of the seed is a knee-knocking grade B movie. There's post-dispersal predation, microbial degradation, competition from the older plants out there, and mechanical destruction by feet or gadgets of those animals around us. Just when you think you've found a nice place to emerge, your microsite gets destroyed. Greta Garbo said it, and she wasn't even a seed, 
"I want to be alone."

You're not just throwing glass marbles on the ground, but complex, highly evolved diaspores. Let's have some respect. I'm longing for some respect. You know these words:

Longing is like the Seed

That wrestles in the Ground,

Believing if it intercede

It shall at length be found.

The Hour, and the Clime-

Each Circumstance unknown,

What Constancy must be achieved

Before it see the Sun!

by Emily Dickinson

\section{Background References}

Baskin, C.C. and J.M. Baskin. 1998. Seeds. Ecology, Biogeography, and Evolution of Dormancy and Germination. Academic Press:San Diego.
Chambers, J.C. and J.A. MacMahon. 1994. A day in the life of a seed: movements and fates of seeds and their implications for natural and managed systems. Annual Review of Ecology and Systematics 25:263-292.

Estrada, A. and T.H. Fleming (eds). 1986. Frugivores and Seed Dispersal. Dordrecht: Dr W. Junk Publishers.

Galatowitsch, S. 2008. Seedling establishment in restored ecosystems. Pages 352-370 in M.A. Leck, V.T. Parker and R.L. Simpson (eds). Seedling Ecology and Evolution. Cambridge: Cambridge University Press.

Harper, J.L. 1977. The Population Biology of Plants. New York: Academic Press.

Howe, H.F. and L.C. Westley. 1988. Ecological Relationships of Plants and Animals. New York: Oxford University Press.

Janzen, D.H. 1969. Seed-eaters versus seed size, number, toxicity and dispersal. Evolution 23:1-27.

Leck, M.A., V.T. Parker and R.L. Simpson. 1989. Ecology of Soil Seed Banks. San Diego CA: Academic Press.

Silvertown, J.W. 2009. An Orchard Invisible, a Natural History of Seeds. Chicago: University of Chicago Press.

Silvertown, J.W. and J.L. Doust. 1993. Introduction to Plant Population Biology. Oxford: Blackwell Scientific Publications. 